\title{
Effect of dietary Black pepper (Piper nigrum) on the performance of broiler
}

\author{
EK Ndelekwute* ${ }^{1}, \mathrm{KD}_{\text {Afolabi }}{ }^{1}$, HO Uzegbu ${ }^{2}$, UL Unah $^{1}$ and KU Amaefule ${ }^{3}$ \\ ${ }^{1}$ Department of Animal Science, University of Uyo, Uyo 520003, Nigeria; ${ }^{2}$ National Agricultural Extension \\ Research, Liaison Station, Ahmadu Bello University, Zaria, Nigeria; ${ }^{3}$ Department of Animal Nutrition and Forage \\ Science, Michael Okpara University of Agriculture, Umudike, Nigeria
}

\begin{abstract}
An experiment was conducted to determine the dietary effect of different levels of ground black pepper (Piper nigrum) on growth performance and apparent nutrient digestibility of broiler chickens. There were five dietary treatments each containing $0,0.25,0.50,0.75$ and $1.00 \%$ black pepper (BP) fed at both starter and finisher phases. One hundred and fifty (150) day old chicks of Arbor-acre strain were divided into five dietary groups having three replication with 10 in each. The five dietary treatments were randomly assigned into five groups. The birds were fed and watered ad libitum. At the starter phase 0.25 and $0.5 \%$ BP improved live weight significantly $(p<0.05)$. Feed intake was significantly $(p<0.05)$ reduced at $1.00 \%$ BP. There were no significant differences $(P>0.05)$ in daily gain, feed: gain ratio and protein efficiency ratio. At the finisher phase, final live weight was improved by $0.25 \%(p<0.05)$. Final live weight, feed intake, weight gain, feed: gain ratio and protein efficiency ratio were negatively affected by 0.75 and $1.0 \% \mathrm{BP}$. Fecal moisture was significantly $(\mathrm{P}<0.05)$ reduced by $0.25 \%$ while dry matter, protein and ether extract digestibility were improved by all the levels of BP. None of the BP levels improved crude fibre digestibility $(p>0.05)$ over the control. NFE and energy utilization were improved by 0.25 and $0.5 \%$, but significantly $(p<0.05)$ reduced by $1.00 \%$ BP.
\end{abstract}

Key words: apparent nutrient digestibility, black pepper, broiler chickens, growth performance

Bangladesh Animal Husbandry Association. All rights reserved. Bang. J. Anim. Sci. 2015.44 (2): 120-127

\section{I ntroduction}

With the increasing demand of poultry meat over the world, poultry farmers want to improve the productivity of their broiler chickens. They are interested in the type of feed that could achieve this in a good period of time. This challenge has necessitated poultry nutritionists to offer certain nutritional strategies for rapid growth of broilers. Feed additives that promote growth have been recommended as one of the strategic options. Pharmaceutical antibiotics as one of the options have been widely used (Maynard et al. 1984), but drug resistance problem emanating from their use has made nutritionists to look inwards for alternative feed additives to antibiotics. Such feed additives are probiotics (Cheeson 1994; Ziggers 2009), prebiotic (Simmering and Blaut 2001; Patterson and Burkholder 2003; Gibson et al. 2004), yeast culture (Raju et al. 2006; Banerjee 2007; Gao et al. 2008), organic acids (Leeson et al.
2005; Marco 2008; Ndelekwute et al. 2012, 2013, 2014) and feed grade enzymes (Choct 2007). The search is continuing and plant materials otherwise known as phytogenics have been adjudged to be good alternatives (Platel and Sirinivasan 2004; Wei and Shibamoto 2007; Ndelekwute et al. 2015).

Phytogenic compounds such as essential oils and spices have been reported to exhibit growth promoting properties (Duke 1994; Gwendolyn 2002; Alciceck et al. 2003; Chand et al. 2005; Windisch et al. 2007). Considering the health hazard, the feed manufacturer and poultry rearer's have been actively looking for an efficacious alternatives. Black paper could be one of the alternative growth promoting source. Black pepper is a spice which is reported to have antibacterial and antioxidant properties in addition to its ability to enhance secretions of gastric and pancreatic enzymes thereby improving digestibility (Orav et al. 2004; 
Sirinivasan 2007). Generally, spices are reported to have positive effect on villi, nutrient absorption and digestal viscosity (Lee et al. 2004a; Lee et al. 2004b; Sirinivasan 2007). These positive properties could be explored for better broiler productivity. Therefore, the objective of the experiment was to determine the effect of black pepper on growth performance and nutrient digestibility of broiler chickens.

\section{Materials and Methods}

The experiment was conducted at the Teaching and Research Farm of Department of Nutrition and Forage Science of the Michael Okpara University of Agriculture, Umudike, Nigeria for period of 7 weeks.

One hundred and fifty (150) day old chicks of Arbor-acres strain were divided into five dietary groups having three replication with 10 in each. The five dietary treatments were randomly assigned into five groups in a completely randomized design (CRD). The five dietary treatments are : $\mathrm{BP} 1=$ diet without $\mathrm{BP}$ (control), BP2 = diet with $0.25 \% \mathrm{BP}, \mathrm{BP} 3=$ diet with $0.5 \% \mathrm{BP}, \mathrm{BP} 4=$ diet with $0.75 \%$ and $\mathrm{BP} 5$ $=$ diet with $1.0 \% \mathrm{BP}$. The diets were isonitrogenous (22\%) and isoenergetic (12 $\mathrm{MJ} \mathrm{ME} / \mathrm{kg}$ ) for the starter diet (Table 1) and also finisher diet (20\% CP and $12.00 \quad \mathrm{MJME} / \mathrm{kg}$ ) (Table 2). Trial and error method using Microsoft Excel package according to Ndelekwute et al. (2014) was used to formulate the diets.

The black pepper seeds used in this study were purchased from the market in dry form. The seeds were separated from some stalk debris contained in the mixture. Thereafter, the seeds were ground into powder form and stored in an air-tight plastic container.

The birds were stabilized for one week in the brooding room with control diet (BP1). At the second week, the birds were weighed and divided into five dietary groups and transferred to a rearing house covered with water proof material where brooding continued till the third week. Five experimental starter diets were supplied randomly into five groups up to fourth week. The five finisher diets were also offered to five respective groups for last three weeks. The birds were vaccinated against Newcastle disease and Infectious bursal disease. The birds were weighed out in every week and feed intake was also recorded. At the end of the feeding experiment, a digestibility trial was conducted in a metabolism cases. The metabolism cages used were thoroughly washed and disinfected. One bird from each of the three replicates of a treatment was transferred to a metabolism cage. The birds were acclimatized for four days in the cages with the respective diets. Feces was collected and weighed for three days at the same time the feed intake of each bird was recorded for three days. Collected fecal samples were oven dried at $60^{\circ} \mathrm{C}$ to constant weight. Dry fecal samples were ground to pass $1 \mathrm{~mm}$ sieve and stored in a refrigerator. Chemical compositions of feed and faeces samples were determined according to the method described in AOAC (1990). Metabolizable energy value of feed and faeces were also calculated.

Data for live weight and feed and nutrient intake were recorded and used to calculate the feed: gain ratio and protein efficiency ratio. All data collected were subjected to analysis of variance (ANOVA). Significant means were separated using Duncan New Multiple Range Test (DNMRT) according to Steel and Torrie (1980).

\section{Results}

Effect of black pepper on feed intake and performance of broiler at the starter phase is shown in Table 3. The initial live weight of the chicks at the end of the stabilization period showed no significant differences $(p>.05)$. Final live weight and feed intake were significantly $(P<0.05)$ influenced due to different levels of Black paper inclusion. Black pepper induced dose dependent influence on the parameters both significantly $(P<0.05)$ and marginally $(P>0.05)$ expressed. BP at 0.25 and $0.50 \%$ produced heavier body weight compared to the control (BP1). At $1.00 \%$, there was a significant reduction in live weight at the same time and $1.0 \%$ BP negatively affected feed intake. 
However, there were no significant differences $(P>0.05)$ in feed: gain ratio, protein intake and protein efficiency ratio. The effect of supplimentation of BP on finisher broiler performance is shown on Table 4. All the parameters were significantly $(P<0.05)$ influenced. While $0.25 \%$ produced the highest live weight, 0.75 and $1.00 \%$ recorded the lowest. There was no significant difference between the control (BP1) and $0.50 \%$ (BP3). Daily gain produced by $0.25 \%$ (BP2) though similar to the control was significantly better than the other levels. Beyond $0.50 \%$, daily gain significantly $(P<0 / 05)$ reduced compared to the control. Feed intake was significantly $(P<0.05)$ depressed at 0.75 (BP4) and $1.00 \%$ (BP5).
Similar trend was also observed in feed: gain ratio, protein intake and protein efficiency ratio. Table 5 shows the effect of black pepper on fecal moisture and nutrients digestibility of the broiler. All the indices considered were significantly $(P<0.05)$ influenced by black pepper addition except fibre in comparison to the control. Fecal moisture did not reduce beyond $0.25 \%$ level. Black pepper showed dose related improvement on dry matter, crude protein and either extract digestibility which increased as the level of black pepper was increased. Digestibility of nitrogen free extract and Metabolizable energy utilization were significantly $(P<0.05)$ reduced by black pepper at $1.0 \%$ but were improved at 0.25 and $0.5 \%$.

Table 1. Ingredients and Nutrients Composition of Starter Diets

\begin{tabular}{|c|c|c|c|c|c|}
\hline Parameters (\%) & $\begin{array}{c}\text { BP1 } \\
(0.00 \%)\end{array}$ & $\begin{array}{c}\text { BP2 } \\
(0.25 \%)\end{array}$ & $\begin{array}{c}\text { BP3 } \\
(0.50 \%)\end{array}$ & $\begin{array}{c}\text { BP4 } \\
(0.75 \%)\end{array}$ & $\begin{array}{c}\text { BP5 } \\
(1.0 \%)\end{array}$ \\
\hline Maize & 55.0 & 55.0 & 55.0 & 55.0 & 55.0 \\
\hline Soybean meal & 28.0 & 28.0 & 28.0 & 28.0 & 28.0 \\
\hline Fish meal & 3.00 & 3.00 & 3.00 & 3.00 & 3.00 \\
\hline Palm kernel cake & 10.3 & 10.1 & 9.8 & 9.55 & 9.30 \\
\hline Bone meal & 3.0 & 3.0 & 3.0 & 3.0 & 3.0 \\
\hline Black pepper & - & 0.25 & 0.50 & 0.75 & 1.00 \\
\hline Salt $\{\mathrm{NaCl})$ & 0.25 & 0.25 & 0.25 & 0.25 & 0.25 \\
\hline Lysine & 0.10 & 0.10 & 0.10 & 0.10 & 0.10 \\
\hline Methionine & 0.10 & 0.10 & 0.10 & 0.10 & 0.10 \\
\hline Premix* & 0.25 & 0.25 & 0.25 & 0.25 & 0.25 \\
\hline Total & 100 & 100 & 100 & 100 & 100 \\
\hline \multicolumn{6}{|c|}{ Chemical composition } \\
\hline \multicolumn{6}{|l|}{$(\%)$} \\
\hline Crude protein & 22.1 & 22.1 & 22.1 & 22.0 & 22.0 \\
\hline Ether extract & 3.92 & 3.94 & 3.96 & 3.98 & 4.00 \\
\hline Crude fibre & 5.01 & 4.98 & 4.95 & 4.92 & 4.89 \\
\hline Ash & 7.04 & 7.05 & 7.06 & 7.07 & 7.08 \\
\hline NFE & 52.5 & 52.3 & 52.2 & 52.2 & 52.1 \\
\hline Calcium & 1.20 & 1.20 & 1.20 & 1.10 & 1.10 \\
\hline Phosphorous & 1.01 & 1.01 & 1.01 & 1.00 & 1.00 \\
\hline Lysine & 1.12 & 1.12 & 1.12 & 1.12 & 1.12 \\
\hline Methionine & 0.65 & 0.65 & 0.65 & 0.65 & 0.65 \\
\hline Energy (MJ ME/kg) & 12.0 & 12.0 & 12.0 & 12.1 & 12.1 \\
\hline
\end{tabular}

* premix supplied per kg diet: vitamin A 15,000 I.U, vitamin $D_{3} 13000$ iu, thiamin 2mg, Riboflavin 6mg, pyridoxine $4 \mathrm{mg}$, Niancin $40 \mathrm{mg}$, cobalamine $0.05 \mathrm{~g}$, Biotin $0.08 \mathrm{mg}$, chooline chloride $0.05 \mathrm{~g}$, Manganese $0.096 \mathrm{~g}$, Zinc $0.06 \mathrm{~g}$, I ron $0.024 \mathrm{~g}$, Copper $0.006 \mathrm{~g}$, I odine $0.014 \mathrm{~g}$, Selenium $0.24 \mathrm{mg}$, Cobalt $0.024 \mathrm{mg}$ and Antioxidant $0.125 \mathrm{~g}$. BP $=$ Black pepper. NFE $=$ Nitrogen free extract. 
Ndelekwute el al. (2015) Bang. J. Anim. Sci. 44(2): 120-127

Table 2. Ingredients and Nutrients Composition of Finisher Diets

\begin{tabular}{|c|c|c|c|c|c|}
\hline Parameters (\%) & $\begin{array}{c}\text { BP1 } \\
(0.00 \%)\end{array}$ & $\begin{array}{c}\text { BP2 } \\
(0.25 \%)\end{array}$ & $\begin{array}{c}\text { BP3 } \\
(0.50 \%)\end{array}$ & $\begin{array}{c}\text { BP4 } \\
(0.75 \%)\end{array}$ & $\begin{array}{c}\text { BP5 } \\
(1.0 \%)\end{array}$ \\
\hline Maize & 56.0 & 56.0 & 56.0 & 56.0 & 56.0 \\
\hline Soybean meal & 25.0 & 25.0 & 25.0 & 25.0 & 25.0 \\
\hline Fish meal & 3.00 & 3.00 & 3.00 & 3.00 & 3.00 \\
\hline Palm kernel cake & 13.3 & 13.1 & 12.8 & 12.6 & 12.3 \\
\hline Bone meal & 3.0 & 3.0 & 3.0 & 3.0 & 3.0 \\
\hline Black pepper & - & 0.25 & 0.50 & 0.75 & 1.00 \\
\hline Salt $\{\mathrm{NaCl})$ & 0.25 & 0.25 & 0.25 & 0.25 & 0.25 \\
\hline Lysine & 0.10 & 0.10 & 0.10 & 0.10 & 0.10 \\
\hline Methionine & 0.10 & 0.10 & 0.10 & 0.10 & 0.10 \\
\hline Premix* & 0.25 & 0.25 & 0.25 & 0.25 & 0.25 \\
\hline Total & 100 & 100 & 100 & 100 & 100 \\
\hline \multicolumn{6}{|c|}{ Chemical composition (\%) } \\
\hline Crude protein & 20.2 & 20.1 & 20.1 & 20.0 & 20.0 \\
\hline Ether extract & 6.20 & 6.21 & 6.21 & 6.30 & 6.30 \\
\hline Crude fibre & 6.20 & 6.20 & 6.10 & 6.10 & 6.10 \\
\hline Ash & 6.80 & 6.80 & 6.88 & 6.89 & 7.08 \\
\hline NFE & 53.1 & 53.2 & 53.2 & 53.2 & 52.98 \\
\hline Calcium & 1.11 & 1.11 & 1.11 & 1.01 & 1.00 \\
\hline Phosphorous & 0.88 & 0.87 & 0.86 & 0.85 & 0.84 \\
\hline Lysine & 1.05 & 1.04 & 1.03 & 1.02 & 1.01 \\
\hline Methionine & 0.50 & 0.49 & 0.48 & 0.47 & 0.46 \\
\hline Energy (MJ ME/kg) & 12.0 & 12.1 & 12.1 & 12.1 & 12.1 \\
\hline
\end{tabular}

*premix supplied per kg diet: vitamin A 15,000 I.U, vitamin $D_{3} 13000$ iu, thiamine 2mg, Riboflavin $6 \mathrm{mg}$, pyridoxine $4 \mathrm{mg}$, Niacin 40mg, cobalamine $0.05 \mathrm{~g}$, Biotin $0.08 \mathrm{mg}$, choline chloride $0.05 \mathrm{~g}$, Manganese $0.096 \mathrm{~g}$, Zinc $0.06 \mathrm{~g}$, I ron $0.024 \mathrm{~g}$, Copper $0.006 \mathrm{~g}$, I odine $0.014 \mathrm{~g}$, Selenium $0.24 \mathrm{mg}$, Cobalt $0.024 \mathrm{mg}$ and Antioxidant $0.125 \mathrm{~g}$. BP $=$ Black pepper. NFE $=$ Nitrogen free extract.

Table 3. Effect of Black Pepper on Performance of Starter Broiler Chicks

\begin{tabular}{lcccccc}
\hline Parameters & BP1 & BP2 & BP3 & BP4 & BP5 & SEM \\
& $(\mathbf{0 . 0 \%})$ & $(\mathbf{. 2 5 \% )}$ & $\mathbf{( 0 . 5 0 \% )}$ & $(\mathbf{0 . 7 5 \% )}$ & $\mathbf{( 1 . 0 \% )}$ & \\
\hline Initial body weight (g) & 113 & 113 & 111 & 109 & 108 & 3.11 \\
Final body weight (g) & $820^{\mathrm{bc}}$ & $890^{\mathrm{a}}$ & $892^{\mathrm{a}}$ & $851^{\mathrm{ab}}$ & $792^{\mathrm{c}}$ & 13.0 \\
Daily weight gain (g) & 33.70 & 37.00 & 37.20 & 35.30 & 32.50 & 2.18 \\
Daily feed intake (g) & $69.00^{\mathrm{a}}$ & $70.30^{\mathrm{a}}$ & $69.00^{\mathrm{a}}$ & $67.20^{\mathrm{ab}}$ & $65.40^{\mathrm{b}}$ & 2.16 \\
Feed: gain ratio & 2.05 & 2.00 & 1.86 & 1.90 & 2.00 & 0.04 \\
Daily protein intake (g/bird) & 14.80 & 15.00 & 14.80 & 14.34 & 2.30 & 1.21 \\
Protein efficiency ratio & 2.28 & 2.46 & 2.52 & 2.45 & 2.32 & 0.13 \\
\hline
\end{tabular}

abc. Means along the same row with different superscripts are significantly different at $P<0.05$. SEM $=$ Standard error of the means. BP = Black pepper. 
Table 4: Effect of Black Pepper on Performance of Finisher Broilers

\begin{tabular}{lllllll}
\hline Parameters & BP1 & BP2 & BP3 & BP4 & BP5 & SEM \\
& $\mathbf{( 0 . 0 0 \% )}$ & $\mathbf{( 0 . 2 5 \% )}$ & $\mathbf{( 0 . 5 0 \% )}$ & $\mathbf{( 0 . 7 5 \% )}$ & $\mathbf{( 1 . 0 \% )}$ & \\
\hline Initial body weight (g) & $820 \mathrm{bc}$ & $890 \mathrm{a}$ & $892 \mathrm{a}$ & $851 \mathrm{~b}$ & $792 \mathrm{c}$ & 13.0 \\
Final live weight g/bird & $1984^{\mathrm{b}}$ & $2104^{\mathrm{a}}$ & $1968^{\mathrm{b}}$ & $1755^{\mathrm{c}}$ & $1716^{\mathrm{c}}$ & 65.7 \\
Daily weight gain g/bird & $55.40^{\mathrm{ab}}$ & $57.80^{\mathrm{a}}$ & $51.20^{\mathrm{b}}$ & $43.00^{\mathrm{c}}$ & $44.00^{\mathrm{c}}$ & 2.60 \\
Daily feed intake g/bird & $128^{\mathrm{ab}}$ & $134^{\mathrm{a}}$ & $119 \mathrm{~b}^{\mathrm{c}}$ & $115^{\mathrm{c}}$ & $111^{\mathrm{c}}$ & 21.80 \\
Feed: gain ratio & $2.30^{\mathrm{b}}$ & $2.32 \mathrm{~b}$ & $2.33 \mathrm{~b}$ & $2.66 \mathrm{a}$ & $2.52 \mathrm{a}$ & 0.15 \\
Daily protein intake g/bird & $25.30^{\mathrm{ab}}$ & $26.70^{\mathrm{a}}$ & $23.10^{\mathrm{ab}}$ & $22.70^{\mathrm{b}}$ & $22.00^{\mathrm{b}}$ & 3.65 \\
Protein efficiency ratio & $2.19^{\mathrm{a}}$ & $2.17^{\mathrm{a}}$ & $2.16^{\mathrm{a}}$ & $1.89^{\mathrm{b}}$ & $2.00^{\mathrm{b}}$ & 0.09 \\
\hline
\end{tabular}

$a b c$. Means along the same row with different superscripts are significantly different at $P<0.05$. SEM $=$ Standard error of the means. $\mathrm{CON}=$ Control, BP $=$ Black pepper.

Table: 5. Effect of Black Pepper on Fecal moisture and Nutrient Digestibility

\begin{tabular}{lcccccc}
\hline Parameters (\%) & $\begin{array}{c}\text { BP1 } \\
(\mathbf{0 . 0 0 \%})\end{array}$ & $\begin{array}{c}\text { BP2 } \\
(\mathbf{0 . 2 5 \% )}\end{array}$ & $\begin{array}{c}\text { BP3 } \\
(\mathbf{0 . 5 0 \%})\end{array}$ & $\begin{array}{c}\text { BP4 } \\
(\mathbf{0 . 7 5 \%})\end{array}$ & $\begin{array}{c}\text { BP5 } \\
(\mathbf{1 . 0 \%})\end{array}$ & SEM \\
\hline Fecal Moisture & $73.1^{\mathrm{a}}$ & $61.8^{\mathrm{b}}$ & $74.8^{\mathrm{a}}$ & $76.4^{\mathrm{a}}$ & $78.0^{\mathrm{a}}$ & 3.34 \\
Dry matter & $68.3^{\mathrm{b}}$ & $76.6^{\mathrm{a}}$ & $77.3^{\mathrm{a}}$ & $78.0^{\mathrm{a}}$ & $78.9^{\mathrm{a}}$ & 4.08 \\
Crude protein & $61.1^{\mathrm{b}}$ & $78.3^{\mathrm{a}}$ & $81.6^{\mathrm{a}}$ & $82.6^{\mathrm{a}}$ & $82.7^{\mathrm{a}}$ & 4.89 \\
Crude fibre $_{\text {Ether extract }}$ & $38.6^{\mathrm{ab}}$ & $39.6^{\mathrm{ab}}$ & $38.3^{\mathrm{b}}$ & $40.30^{\mathrm{ab}}$ & $41.4^{\mathrm{a}}$ & 2.01 \\
NFE & $78.0^{\mathrm{b}}$ & $86.3^{\mathrm{a}}$ & $88.9^{\mathrm{a}}$ & $87.4^{\mathrm{a}}$ & $87.2^{\mathrm{a}}$ & 5.08 \\
\hline
\end{tabular}

abc. Means along the same row with different superscripts are significantly different at $P<0.05$. SEM $=$ Standard error of the means. BP $=$ Black pepper. NFE $=$ Nitrogen free extract.

\section{Discussion}

The reduction in live weight at $1.0 \%$ level of the black pepper at the starter phase signifies that at a higher level black pepper could become detrimental to growth. Abaza et al. (2008) reported improvement in live weight and weight gain of broiler chickens feed $0.1 \%$ black pepper oil at 4 weeks of age, confirming the importance of black pepper as growth promoting additive. Poor feed intake at $1.0 \%$ could be linked to the poor growth recorded at that level. Despite the fact that the feed: gain ratio was not significant black pepper at each level showed marginal superiority in the three parameters mentioned. According to Abaza et al. (2008) overall feed intake was lowered in chicks fed higher level of black pepper thus supporting this work. However, their earlier work, Abaza et al. (2003) contradicted the present work if feed: gain ratio is to be considered. They reported that $0.25 \%$ black pepper improved feed gain: ratio.

Performance trend at this phase could be used to show that the initial body weight which was significantly $(P<0.05)$ different, could not have significantly contributed to the result of the final live weight of the birds. The black pepper could have constituted the main factor that significantly influenced the final live weight at the finisher phase. There were two clear reasons for these assertions. First, the live weight produced by $0.75 \%$ at the starter phase was numerically higher than the control, but at the end of the experiment it became significantly inferior to the control indicating negative effect of the black pepper at that level. Secondly, $0.50 \%$ at the starter phase produced live weight which was significantly higher than the control, but at the end of the finisher phase it was similar to the control. Based on this, it could be said that prolong feeding of black 
pepper at $0.50 \%$ and above could be detrimental. From available reports, not much have been said concerning the use of black pepper seeds in poultry diets, but the result on body weight especially at $0.25 \%$ was consistent with some reports on other spices (Windisch et al. 2007); herbs (Lee et al. 2004a); plant extracts (Chand et al. 2005; Mushtag et al., 2007 ; Javed et al. 2009) and essential oils (Abaza et al. 2008). This could be linked to better protein digestibility as shown in Table 5 as earlier reported by Abd EL-Latif et al. (2002).

properties include stimulation of digestive enzymes, saliva, hydrochloric acid and mucus; anti-oxidation effect, ability to improve the number and height of villi, reduction in crypt depth, anti-flatulence ability and anti-microbial activity according to Mathe (1996); Jang et al. (2004); and Sirinivasan (2007).

The negative effect of black pepper at higher levels could be due to the presence of heavy metals such as lead, cadmium, tin and silver (Abou-Arab and Abou Donia 2000), antinutritional factors and terpernoids reported to contain in black pepper which resulted to poor growth (Abaza et al. 2008).

The result of the apparent digestibility of nutrients found in the present experiment are confirmed with the earlier report by Javed et al. (2009) who indicates that the plant extracts at certain levels improved digestibility. Lee et al. (2003) and Windisch et al. (2007) also reported that spices and essential oils could be used to aid digestion in monogastric animals. Many reasons have been ascribed to this. Jang et al. (2004) attributed better nutrient digestion to antimicrobial property of the essential oil in black pepper. Sirinivasan (2007) linked it to the ability of black pepper to induce saliva secretion, hydrochloric acid and mucus production. Other studies have shown that the spices or their active ingredients have positive effect on bile acid secretion (Platel and sirinivasan 2000). Platel and Sirinivasan (2000) attributed that the pungent properties black pepper stimulated digestive enzymes activities. The inability of the black pepper to improve digestibility of fibre could have resulted to the
The lower feed intake at higher levels could be due to pungent characteristics of spices (Lee et al. 2004a) which the black showed. The reduced feed consumption could also be ascribed to strong taste produced by black pepper (black pepper taste hot) in the feed. Lee et al. (2004a) reported that spices produced feed aversion in rodents due to their pungent odour.

Performance of birds fed diet containing $0.25 \%$ black pepper over the control could be attributed to reported growth promoting properties inherent in black pepper. These insignificant reduction of fecal moisture at levels higher than $0.25 \%$.

Poor nitrogen free extract digestibility and energy utilization exhibited at $1.0 \%$ could have been one of the factors that resulted to the poor growth performance of the birds at that level (Table 4). Lee et al. (2004a) had cautioned that high doses of active principles in essential oils of spices could lead to poor digestibility at higher level. This could have been the reason for the poor nitrogen free extract digestibility and energy utilization at $1.0 \%$. Further more, it has been reported that essential oils impaired absorption of alanine in rat (Kerydiyyeh, 2000). The author postulated that it could be due to inhibition of the transport mechanism ( $\mathrm{Na}+-\mathrm{K}+-$ ATPase) in enterocyte by the essential oils. This could be a good reason why 0.75 and $1.0 \%$ black pepper, significantly reduced live weight (Table 4) despite higher protein digestibility. Absorption of alanine and probably other amino acids would have been impaired

\section{References}

Abaza IM, Asar MA, Elshaarrawi GE and Hassan MF (2003). Effect of using Ngella seed, chamomile flower, thyme flower and harmala seed as feed additives on performance of broilers. Egyptian J. Agric. Res. 81; 735 - 749.

Abaza MI, Shehata MA, Shoieb MS and Hassan II (2008). Evaluation of some natural feed additives in growing chicks diets. Int. J. Poult. Sci, 7: 872 - 879.

Abd El-Latif SA, Fatan Ahmed A and El-Kaity AM (2002). Effect of feeding dietary thyme, black cumin, diatus and fennel on 


\section{Effect of Dietary Black Pepper (Piper nigrum)}

productive and some metabolic responses of growing Japanese quail. Egyptian Poult. Sci. 22; 109 - 125

Abou-Arab AAK and Abou Donia MA (2000). Heavy metals in Egyptian spices and medicinal plants and the effect of processing on their levels. J. Agric. and Food Chem. 48: 2300-2304.

Alcicek A, Bozkurt M and Cabuk M (2003). The effect of an essential oil combination derived from selected herbs growing wild in Turkey on broiler performance. South Afri. J. Anim. Feed Sci. 8: 25 - 33.

AOAC (1990). Official Methods of Analysis. $14^{\text {th }}$ edition. Washington D.C., USA.

Banerjee GC (2007). A text book of Animal Husbandry. $8^{\text {th }}$ ed. Oxford and IBH Pub. Co. Pvt Ltd., New Delhi, India. 450 - 467.

Cheeson A (1994). Probiotics and other intestinal mediators. In: Principles of pig science. (Cole, D. J. A., Wiseman, J. and Varley MA Eds.). Nottingham University Press. 197 - 214.

Chand N, Durani FR, Mian MA and Durani Z (2005). Effect of different levels of feed added Berberi lyceum on the performance of broiler chicks. Int. J. Biol. and Biotech. 2; $971-974$.

Choct M (2007). Enzymes in animal nutrition: The unseen benefits. International Research University of New England Pub. Australia. 2 (4); 23 - 25.

Duke JA (1994). Biologically active compounds in important spices. In: Spices, Herbs and Edible Fungi, Charalambous G (ed.), Elsevier Science. 225 - 250.

Gao J, Zhang H J, Yu SH, Wu SG, Yoon I, Quigley JY, Gao P and Qi GH (2008). Effects of yeast culture in broiler diets on performance and immuno modulatory functions. Poult. Sci. 87; 1377 - 1384.

Gibson GR, Robert HM, Van Loo JAE, Rasfall RA and Roberfroid MB (2004). Dietary modulates of the human colomic microbiota: Updating the concept of prebiotics. Nutr. Res. Review. 17; 259 275.

Gwendolyn J (2002). Phytobiotics. In : Phytogenic Additives. Biomin publication Austria. 1; 4 - 15.
Jang IS, Ko YH, Yang HY, Ha JS, Kim JY, Kang SY, Yoo DH, Nam DS, Kimand DH and Lee CY (2004). Influence of essential oil components on growth performance and the functional activity of the pancreas and small intestine in broiler chickens. Asian Aust.J. Anim. Sci. 17; 394 - 400.

Javed M, Durrani FR, Hafeez A, Khan RU and Ahmad I (2009). Effect of aqueous extract of plant mixture on carcass quality of broiler chicks. J. Agric. and Biol. Sci. 4 (1); 37 - 40 .

Kreydiyyeh SI, Usta J, Knio K, Markossian S and Dagher S (2003). Aniseed Oil increases glucose absorption and reduces urine output in the rat. Life Sci. 74; 663 - 673.

Lee $\mathrm{KW}$, Everts $\mathrm{H}$, Kappert $\mathrm{HJ}$, Van Der Klien AG, Lemmens Frehner $M$ and Beynen A G (2004a). Growth performance, intestinal viscosity, fat digestibility and plasma cholesterol in broiler chickens fed a ryecontaining diet without or with essential oil components. Int. J. Poult. Sci. 3 (9); 613 - 618.

Lee KW, Everts $H$ and Beynen AC (2004b). Essential oils in broiler nutrition. Int. J. Poult. Sci. 3 (12); 738 - 252.

Leeson S, Namkung $H$, Ankongiovanni $H$ and Lee EH (2005). Effect of butyric acid on the performance and carcass yield of broiler chickens. Poult. Sci. 84; 1418 1422.

Marco Q (2008). Water quality and broiler performance. Broiler Supervisor's Short Course. Bulletin, New Carolina, USA. 11 13

Mathe A (1996). Essential oils as phytogenic feed additives. In: Essential Oils Basics and Research. Frank $\mathrm{C} \mathrm{H}$, Mathe $\mathrm{A}$ and Bushbaver B (eds), Proceedings, 27th International Symposium. on Essential Oils, Vienna. 315 - 321.

Maynard LA, Loosli J K, Hintz HF and Warner HF (1981). Animal Nutrition $7^{\text {th }}$ ed. Tata McGraw Hill Publihers, New Delhi, India. 122 - 134

Ndelekwute EK, Uzegbu HO, Madu CO, Assam E M (2012). Organic acids as feed additives in pig and poultry diets. A Review. Nigeria Agricultural J ournal. 43: 27 - 38. 
Ndelekwute EK, Amaefule KU, Uzegbu HO, Okereke CO (2013). Effect of finisher diets treated with organic acids on carcass and internal organs of broiler chickens. Nigeria Journal of Animal Production. 40(1): 224 - 231.

Ndelekwute EK, Assam ED, Assam EM. and Amaefule KU (2014). Effect of organic acid treated drinking water on growth of broiler chickens. Nig. J. Anim. Prod. 41(2): 116 - 123.

Ndelekwute E, Enynihi G, Assam E, Ufot U and Otu O (2015). Lime (Citrus auantifolia) juice as a source of natural organic acids can improve the growth of broiler chickens. Proceedings, British Society of Animal Science Vol. 6 Part 2, P220. Olomu JM 1995 Monogastric Animal Nutrition: Principles and Practice. Jachem Publishers, Benin, Nigeria. 80 - 98.

Orav A, Stulova I, Kailas T and Muurisepp M (2004). Effect of storage on essential oil composition of Piper nigrum fruits of different ripening states. J. Agric. and Food Chem. 52; 2582 - 2586.

Patterson JA and Burkholder KM (2003). Application of prebiotics and probiotics in poultry production. Poult. Sci. 82; 627 631.
Platel K and Sirinivasan K (2004). Digestive stimulant action of spices: A myth or reality. Indian J. Med. Res. 119; 167-172

Raju MVIN, Reddy VR, Rama Rao SV and Panda AK (2006). Yeast: A multifunctional feed supplement for poultry. Poult. Int. 45 (7); $16-21$.

Simmering $R$ and Blaut $M$ (2001). Pro and Prebiotics - the tasty guardian angles? Applied Microbial Biotech. 55; 19 - 28

Sirinivasan K (2007). Black pepper and its pungent principle - piperine. A review of diverse physiological effects. Food Sci. and Nutr. 47 ( 8); 735-748.

Steel RGD and Torrie JH (1980). Principles and Procedures of statistics. McGraw Hill International Books Co. Sydney.

Wei A and Shibamoto T (2007). Antioxidant activities and volatile constituents of various essential oils. Journal of Agriculture and Food Chemistry volume 55, 1737 - 1742.

Windisch W, Schedle K, Plitzner C, Kroismayr A (2007). Use of phytogenic products as feed additives for swine and poultry. J. Anim. Sci. 86; 140 - 148.

Ziggers D (2009). Probiotic in animal feed. Feed Tech.13 (4); $20-21$. 